\title{
Efektivitas Sirih Merah dalam Perawatan Luka Perineum di Bidan Praktik Mandiri
}

\section{The Effectiveness of Red Betel in Healing Perineal Wound in Independent Practicioner Midwive}

\author{
Susilo Damarini, Eliana, Mariati
}

\author{
Jurusan Kebidanan Polteknik Kesehatan Kementerian Kesehatan Bengkulu
}

\begin{abstract}
Abstrak
Angka kejadian ruptur perineum pada primipara persalinan normal adalah sekitar $88,9 \%$. Piper crocatum extract atau ekstrak daun sirih merah diketahui mempunyai kandungan kimia yang berefek antiseptik dan antibakteri. Sebagian besar persalinan normal di Kota Bengkulu mengalami ruptur spontan atau episiotomi. Dari 10 persalinan, ada 7 pasien yang mengalami robekan perineum dan kering rata-rata dalam 7 hari, dengan perawatan menggunakan iodin atau merendam/ cebok rebusan daun sirih. Tujuan penelitian ini adalah menilai efektivitas penyembuhan luka perineum ibu nifas dengan menggunakan daun sirih merah dan obat antiseptik. Metode penelitian quasi eksperimental, populasi ibu pospartum dengan luka perineum yang ditolong oleh bidan praktik mandiri. Sampel perlakuan 35 orang dan kelompok kontrol 35 orang. Sampel diambil secara accidental sampling. Waktu penelitian bulan Mei - Agustus 2012 di Kota Bengkulu. Variabel lainnya yaitu status kesehatan, obat antibiotik dan status gizi. Analisis menggunakan uji Mann - Whitney Test. Hasil penelitian menunjukkan bahwa rata-rata lama penyembuhan luka perineum menggunakan infusum sirih merah adalah 2 - 3 hari sedangkan pada kelompok obat antiseptik rata-rata lama penyembuhan $5-6$ hari, artinya bahwa daun sirih merah lebih efektif dibandingkan dengan iodine dalam perawatan luka perineum pada masa pospartum.

Kata kunci: Perawatan perineum, postpartum, sirih merah
\end{abstract}

\footnotetext{
Abstract

The incidence of perineal rupture in primiparous normal deliveries is $88.9 \%$. Piper crocatum Extract or red betel leaf extract are known contained antiseptic and antibacterial effect. Mostly normal deliveries in Bengkulu City experienced spontaneous rupture or episiotomy. From 10 births, 7 patients experienced perineal laceration and were dry in 7 days by treatment using iodine or soak/ wiping with betel leaf decoction. The aim of this study was to determine the effectiveness of red betel leaf in healing perineal wound of postpartum mother in Independent Practice Midwife in Bengkulu City 2013.
}

The method of this study was quasi-experimental. The population was mothers with postpartum perineal wounds who attended by independent midwive practice. 35 sample as treatment group and 35 people as control group. Sample was taken by accidental samplingthis study doing at month May - August 2012 in The Bengkulu City. Other variables are health status, antibiotics and nutritional status. Analysis using the Mann - Whitney Test. The result of this study showed that the avarage length of perineal wound healing using infusum of red betel leaf was $2-3$ days, while in group iodine was $5-6$ days, meaning that red betel leaf is more effective compared with iodine in wound care in the puerperium.

Keywords: Perineal care, postpartum, red betel leaf

\section{Pendahuluan}

Infeksi postpartum adalah penyebab kematian maternal yang merupakan urutan kedua setelah perdarahan jika tidak segera ditangani. ${ }^{1}$ Infeksi postpartum terjadi di traktus genitalia setelah kelahiran yang diakibatkan oleh bakteri. Hal ini akan meningkatkan risiko infeksi postpartum yang salah satunya disebabkan oleh luka episiotomi yang dapat menyebabkan shock septic. ${ }^{2}$

Ruptur perineum adalah robekan yang terjadi pada saat bayi lahir baik secara spontan maupun dengan menggunakan alat atau tindakan. Robekan perineum umumnya terjadi pada garis tengah dan bisa menjadi luas apabila kepala janin lahir terlalu cepat. Robekan perineum terjadi pada hampir semua primipara. ${ }^{3}$ Ruptur Perineum dapat terjadi karena ruptur spontan maupun episiotomi. Sebagian besar ibu bersalin mengalami

Alamat Korespondensi: Susilo Damarini, Jurusan Kebidanan Poltekkes Kemenkes Bengkulu, Jl Indragiri No. 03 Padang Harapan Bengkulu, Hp. 081377561277,e-mail: s.damarini@yahoo.com 
robekan pada vagina dan perineum yang memberikan perdarahan dalam jumlah bervariasi. Oleh karena itu, diperlukan penjahitan pada perineum. Lama penyembuhan luka jahitan perineum akan berlangsung $7-10$ hari dan tidak lebih dari 14 hari. Perawatan luka perineum pada ibu setelah melahirkan berguna untuk mengurangi rasa ketidaknyamanan, menjaga kebersihan, mencegah infeksi dan mempercepat penyembuhan. Perawatan perineum umumnya bersamaan dengan perawatan vulva. Hal-hal yang perlu diperhatikan adalah mencegah kontaminasi dengan rektum, menangani dengan lembut jaringan luka, membersihkan darah yang menjadi sumber infeksi dan bau. ${ }^{4}$

Pada persalinan normal, dengan ruptur perineum dapat terjadi infeksi perineum karena kebersihan perineum yang kurang terjaga. Gejalanya cukup mudah untuk dilihat, yaitu berupa rasa panas dan perih pada tempat yang terinfeksi, perih saat buang air kecil, demam dan keluar cairan seperti keputihan yang berbau. Hal ini dapat dicegah dengan merawat luka menggunakan bath seat, yakni berjongkok atau duduk, kemudian membasuh bekas luka dengan cairan antiseptik. ${ }^{5}$ Faktor yang memengaruhi perawatan luka perineum adalah faktor eksternal (lingkungan, tradisi, pengetahuan, sosial ekonomi, penanganan petugas, kondisi ibu dan gizi) dan faktor internal (usia, penanganan jaringan, hemoragi, hipovolemia, faktor lokal edema, defisit nutrisi, personal higiene, defisit oksigen, medikasi dan aktivitas berlebih) ${ }^{6}$

Menurut penelitian, piper crocatum extract atau ekstrak daun sirih merah diketahui mempunyai kandungan kimia yang berefek antiseptik dan antibakteri. ${ }^{7}$ Daun sirih merah mempunyai daya antiseptik dua kali lebih tinggi dari daun sirih hijau. Kandungan kimia dalam ekstrak sirih merah antara lain adalah minyak atsiri, hidroksikavikol, kavikol, kavibetol, alilprokatekol, karvakrol, eugenol, p-cymene, cineole, cariofelen, kadimen estragol, terpen dan fenil propada. Karvakrol bersifat desinfektan dan antijamur sehingga digunakan sebagai obat antiseptik.

Ekstrak sirih merah mengandung flavonoid, alkaloid, tannin dan minyak atsiri yang terutama bersifat sebagai antimikroba. Penelitian membuktikan bahwa ekstrak sirih merah mempunyai efek antibakteri terhadap Staphylococcus aureus dan Eschericia coli. Penelitian menggunakan metode eksperimental laboratorium untuk membuktikan kemampuan antibakteri ekstrak sirih merah (Piper crocatum) terhadap bakteri standar laboratorium. Bakteri gram positif pada penelitian ini dilakukan pada Staphylococcus aures sementara untuk bakteri gram negatif dilakukan pada Escherichia coli. Penelitian meliputi preparasi sampel, pembuatan ekstrak, dan uji daya antibakteri. Hasil penelitiannya menunjukkan Ekstrak etanol sirih merah mempunyai kemampuan antibakteri terhadap bakteri gram positif dan bakteri gram negatif khususnya terhadap Staphylococcus aureus ATCC 25923 dan Escherichia coli ATCC 35218 dan Kadar Hambat Minimal (KHM) ekstrak etanol sirih merah terhadap Staphylococcus aureus (gram positif) cenderung pada kadar 25\%. ${ }^{8}$ Berdasarkan hasil penelitian tersebut, dapat dikembangkan untuk diterapkan sebagai obat luar pada perawatan luka.

Penelitian terdahulu pada 5 bidan praktik mandiri Kota Bengkulu, menemukan dari 10 pasien persalinan rata-rata yang mengalami ruptur spontan atau episiotomi ada 7 pasien dan kering rata-rata dalam 7 hari. Perawatan menggunakan obat antiseptik, selain itu ada juga pasien yang melakukan perawatan luka dengan cara merendam dengan rebusan daun sirih atau digunakan untuk cebok, luka kering rata-rata sama dengan menggunakan obat antiseptik. Berdasarkan penelitian dan data survei terdahulu, peneliti tertarik untuk melakukan penelitian perawatan luka perineum pada ibu nifas dengan menggunakan daun sirih merah pada pasien persalin-an di bidan praktik mandiri. Penelitian ini bertujuan untuk mengetahui efektivitas penggunaan infusum daun sirih merah untuk perawatan luka perineum pada masa nifas.

\section{Metode}

Penelitian dilakukan di beberapa bidan praktik swasta yang berada di Kota Bengkulu, mulai dari bulan Mei sampai dengan Agustus 2012. Sampel berjumlah 70 responden yang terdiri dari 35 pada kelompok intervensi dan 35 pada kelompok kontrol di ambil dengan teknik accident-al dengan kriteria inklusi. Ibu nifas yang bersedia menjadi responden adalah ibu nifas yang ditolong oleh bidan praktik mandiri, ibu nifas hari pertama yang mengalami luka heacting perineum.

Penelitian menggunakan rancangan eksperimen semu, dengan dua kelompok sampel, satu kelompok intervensi perawatan perineum dengan menggunakan infusum daun sirih merah dan obat antibiotik oral amoxicillin $500 \mathrm{mg}$ dengan dosis 3 kali 1 perhari. Kelompok kontrol dengan menggunakan iodin dan obat antibiotik oral dengan jenis dan dosis yang sama dengan kelompok perlakuan. Bahan Infusa daun sirih merah adalah campuran daun sirih merah dengan air panas $100^{\circ} \mathrm{C}$, dengan konsentrasi $25 \% .{ }^{9}$ Kemudian campuran diendapkan lalu diambil larutannya, dan dapat digunakan dengan cara mengoles/totol-totol pada luka perineum setiap selesai cebok. Daun sirih merah dipilih yang bagus dengan umur minimal 4 bulan, dicuci bersih pada air mengalir, kemudian dihaluskan. Perlakuan diberikan pada hari pertama postpartum dan selanjutnya dilakukan pengukuran lama penyembuhan luka perineum melalui observasi selama 7 hari. Pengukuran juga dilakukan terhadap kepatuhan ibu dalam konsumsi obat antibiotik, ibu yang tidak patuh diklasifikasikan tidak mengonsumsi antibiotik. 
Hasil penelitian disajikan dalam analisis univariat dari setiap variabel independen dan dependen. Penyajian dilanjutkan dengan hasil analisis bivariat yang bertujuan untuk mengetahui efektivitas daun sirih merah terhadap lama penyembuhan luka perineum. Pada analisis univariat juga dilakukan uji homogenitas (kesetaraan) antara kelompok intervensi dan kelompok kontrol. Analisis menggunakan uji Mann - Whitney.

\section{Hasil}

Pada kelompok intervensi rata-rata LILA adalah 24,614, lama penyembuhan rata-rata 3,37 hari. Pada kelompok kontrol rata-rata LILA adalah 24,463 dan lama penyembuhan 5,43 hari (Tabel 1). Kondisi kesehatan responden seluruhnya adalah baik. Pada variabel pemberian antibiotik, kelompok intervensi dan kontrol adalah setara hal ini ditunjukkan dengan nilai $\mathrm{p}=0,198(\alpha>0,05)$ (Tabel 2).

Antara kelompok intervensi dan kelompok kontrol mempunyai kesetaraan ukuran LILA (nilai $\mathrm{p}=0,99>\alpha$ $=0,05)$ (Tabel 3). Rata-rata hari perawatan luka perineum menggunakan sirih merah lebih rendah dibandingkan rata-rata hari perawatan luka perineum menggunakan obat antiseptik (Tabel 4).

\section{Pembahasan}

Berdasarkan hasil penelitian dengan analisis MannWhitney Test menunjukkan nilai $\mathrm{p}=0,000(\alpha<0,05)$ berarti rata-rata hari perawatan luka perineum menggunakan sirih merah lebih rendah dibandingkan rata-rata hari perawatan luka perineum menggunakan obat antiseptik, sehingga dapat disimpulkan bahwa daun sirih merah lebih efektif dibandingkan obat antiseptik dalam perawatan luka perineum pada masa nifas. Berdasarkan observasi langsung yang dilakukan oleh para bidan dan berdasarkan pernyataan pasien yang mengatakan bahwa luka perineum dengan menggunakan infusa sirih merah tidak berbau pada genitalia, tidak seperti pengalaman selama ini, perawatan luka perineum menggunakan betadine genitalianya tercium bau menyengat, bau lokhea bercampur obat antiseptik. Penelitian ini sejalan dengan penelitian Wibawati, ${ }^{9}$ yang menunjukkan bahwa pemberian ekstrak daun sirih merah (Piper betle Var. Rubrum) meningkatkan waktu (tiga hari lebih cepat daripada kontrol) kesembuhan luka insisi yang diinfeksi Staphylococcus aureus pada tikus putih.

Daun sirih merah mempunyai banyak kandungan yang sangat bermanfaat bagi kesehatan antara lain mengandung arecoline di seluruh bagian tanaman yang bermanfaat untuk merangsang saraf pusat dan daya pikir, meningkatkan gerakan peristaltik. Dengan peningkatan peristaltik, berarti dapat memperlancar peredaran darah sehingga kandungan oksigen juga menjadi lebih baik sehingga sangat membantu proses penyembuhan luka. Daunnya mengandung eugenol yang mampu mencegah ejakulasi dini, membasmi jamur Candida albicans, dan bersifat analgesik sehingga dapat meredakan rasa nyeri pada luka. Sedangkan kandungan karvakrol bersifat disinfektan dan antijamur sehingga bisa digunakan sebagai antiseptik untuk menghilangkan bau dan keputihan serta mencegah infeksi. Kandungan kimia minyak atsiri dalam daun sirih bertindak sebagai antiseptik dan penghilang bau badan seperti, kadinen, kavikol, sineol, eugenol, karvanol dan zat samak. Selain sebagai ramuan secara eksternal, daun sirih juga bisa digunakan sebagai ramuan penghilang bau badan secara internal atau dengan diminum. 10

Kandungan tannin pada daun sirih merah bermanfaat untuk mengurangi sekresi cairan pada vagina sehingga mempercepat kering pada luka, melindungi fungsi hati,

Tabel 1. Distribusi Responden Berdasarkan Lingkar Lengan Atas (LILA) dan Lama Penyembuhan Luka

\begin{tabular}{llllllll}
\hline Jenis Kelompok & $\mathbf{n}$ & Mean & Median & SD & Minimum & Maksimum & 95\% CI \\
\hline LILA intervensi (cm) & 35 & 24,614 & 24 & 2,2032 & 22 & 36 & $23,857-25,371$ \\
LILA kontrol (cm) & 35 & 24,463 & 24 & 1,6156 & 22 & 32 & $23,908-25,018$ \\
Lama penyembuhan intervensi (hr) & 35 & 3,37 & 3 & 0,843 & 2 & 5 & $3,08-3,66$ \\
Lama penyembuhan kontrol (hr) & 35 & 5,43 & 5 & 0,917 & 4 & 7 & $5,11-5,74$ \\
\hline
\end{tabular}

Tabel 2. Distribusi Responden Berdasarkan Kondisi Kesehatan dan Pemberian Antibiotik di Bidan Praktik Mandiri

\begin{tabular}{cccccccc}
\hline \multirow{2}{*}{ Variabel } & Kelompok Intervensi & Kelompok Kontrol & \multicolumn{2}{c}{ Total } & Nilai p \\
\cline { 2 - 6 } & $\mathbf{n}$ & $\%$ & $\mathbf{n}$ & $\%$ & $\mathbf{n}$ & $\%$ & \\
\hline $\begin{array}{c}\text { Kondisi Kesehatan } \\
\text { Tidak Baik }\end{array}$ & 0 & 0 & & & & & \\
Baik & 35 & 100 & 35 & 100 & 70 & 100 & - \\
$\begin{array}{c}\text { Pemberian Antibiotik } \\
\text { Ya }\end{array}$ & 30 & 85,7 & 34 & 97,1 & 64 & 91,4 & 0,99 \\
Tidak & 5 & 14,3 & 1 & 2,9 & 6 & 8,6 &
\end{tabular}


Tabel 3. Analisis Kesetaraan Ukuran LILA Responden pada Kelompok Intervensi dan Kontrol

\begin{tabular}{lcccc}
\hline Variabel & $\mathbf{n}$ & Mean Rank & Sum of Ranks & Nilai p \\
\hline Kontrol & 35 & 35,64 & 1247,50 & 0,952 \\
Intervensi & 35 & 35,36 & 1237,50 & \\
\hline
\end{tabular}

Tabel 4. Analisis Efektifitas Daun Sirih Merah dalam Perawatan Luka Perineum pada Masa Nifas Dibandingkan dengan Pengunaan Obat Antiseptik

\begin{tabular}{lcccc}
\hline Variabel & $\mathbf{n}$ & Mean Rank & Sum of Ranks & Nilai p \\
\hline Intervensi & 35 & 20,06 & 702 & 0,000 \\
Kontrol & 35 & 50,94 & 1783 & \\
\hline
\end{tabular}

dan mencegah diare. Dengan sifat antiseptiknya, sirih sering juga digunakan untuk menyembuhkan kaki yang luka karena mengandung styptic buat menahan pendarahan dan vulnerary, yang menyembuhkan luka pada kulit. Juga digunakan ibu postpartum untuk mengobati luka perineum dengan cara dicebok ataupun direndam bahkan diminum. ${ }^{10}$

Penelitian ini bertentangan dengan teori yang menyatakan bahwa pada fase inflamasi berlangsung selama 1 sampai 4 hari. ${ }^{5}$ Luka perineum yang tidak dilakukan perawatan dengan baik akan menimbulkan dampak infeksi, yaitu kondisi perineum yang terkena lokhea dan lembab akan sangat menunjang perkembangbiakan bakteri yang dapat menyebabkan timbulnya infeksi pada perineum. Komplikasi, muncul infeksi pada perineum dapat merambat pada saluran kandung kemih ataupun pada jalan lahir yang dapat berakibat pada munculnya komplikasi infeksi kandung kemih maupun infeksi pada jalan lahir. Kematian ibu postpartum, penanganan komplikasi yang lambat dapat menyebabkan kematian pada ibu postpartum mengingat kondisi fisik ibu postpartum masih lemah. ${ }^{11}$ Oleh sebab itu, perlu perhatian perawatan luka perineum karena semua ibu belum tentu mengetahui cara perawatan luka seperti hasil penelitian yang dilakukan di Lamongan. Sebagian besar ibu nifas kurang mengetahui cara perawatan luka perineum, hasil penelitian ini dapat menjadi salah satu solusi dalam perawatan luka perineum secara tepat. ${ }^{12}$

Hasil penelitian ini juga didukung dengan hasil penelitian Majalah Farmasi 164,13 dengan metode uji yang dilakukan (metode replika). Sediaan gel ekstrak daun sirih mempunyai daya antiseptik. Sediaan gel dengan kadar ekstrak daun sirih mulai 15\% mempunyai kemampuan menurunkan mikroorganisme di telapak tangan sampai 57\%, sedangkan kadar ekstrak 25\% mampu menghilangkan semua mikroorganisme. Daya antiseptik sediaan gel ekstrak daun sirih dengan kadar 15\% mempunyai daya antiseptik sama dengan sediaan gel etanol, sedangkan sediaan gel ekstrak daun sirih dengan kadar 20\% dan 25\% mempunyai daya antiseptik sama dengan sediaan gel triklosan. ${ }^{12}$ Selanjutnya didukung teori yang mengatakan tentang khasiat daun sirih merah ini digunakan untuk mengurangi keputihan dan menjaga organ kewanitaan karena salah satu khasiat dari sirih merah adalah sebagai antiseptik, yaitu dengan merebus 7 - 10 lembar daun sirih merah, lalu menggunakan air rebusan tersebut untuk membilas organ kewanitaan. ${ }^{14}$

Daun sirih tergolong tanaman yang mempunyai banyak efek terapi. Di antara kandungan daun sirih tersebut adalah minyak atsiri, hidroksikavicol, kavicol, kavibetol, allylpyrokatekol, cyneole, caryophyllene, cadinene, estragol, terpennena, seskuiterpena, fenil propana, tanin, diastase, gula, dan pati. Di antara kandungan tersebut, sirih mempunyai efek antibiotik, berdasarkan pada efek terapi ini maka sirih juga bisa dijadikan bahan untuk perawatan luka yang biasanya digunakan dengan cara untuk cebok dan rendam, hal seperti ini sudah menjadi tradisi dilakukan oleh ibu-ibu setelah melahirkan. ${ }^{7}$ Hal ini didukung juga dengan hasil penelitian menyatakan bahwa ekstrak etanol daun sirih merah mempunyai kemampuan antibakteri terhadap staphylococcus aureus ATCC 25923 dan Eschericia Coli. Selain itu, daun sirih merah juga mengandung senyawa fitokimia yakni alkoloid, saponin, tanin, dan flavonoid. Selain itu, kandungan kimia lainnya adalah minyak atsiri, hidroksikavicol, kavicol, kavibetol, allyprokatekol, karvakrol, eugenol, pcymene, cineole, caryofelen, kadimen estragol, terpenena, dan fenil propa$d a$. Karvakrol bersifat desinfektan antijamur sehingga bisa digunakan sebagai antiseptik untuk menghilangkan bau mulut dan keputihan. Eugenol bisa mengurangi rasa sakit, selain itu kebanyakan minyak atsiri bersifat sebagai antibakteri dan antijamur yang kuat. ${ }^{8}$ Peneliti lain tentang isolasi jamur endofit dari daun sirih (Piper betle L.) hasilnya menyatakan bahwa sebagai antimikroba terhadap Escherichia coli, Staphylococcus aureus dan Candida albicans. Minyak atsiri daun sirih (P. betle L.) merupakan salah satu minyak atsiri yang bersifat antibakteri. Minyak ini dapat menghambat pertumbuhan beberapa jenis bakteri merugikan seperti Escherichia coli, Salmonella sp, Staphylococcus aureus, Klebsiella dan Pasteurella. ${ }^{15}$ Sirih juga mengandung arecoline di seluruh bagian tanaman. Zat ini bermanfaat untuk merangsang saraf pusat dan daya pikir, meningkatkan gerakan peristaltik. Dengan demikian, sirkulasi darah pada luka menjadi lancar, oksigen menjadi lebih banyak, hal ini dapat memengaruhi penyembuhan luka menjadi lebih cepat. ${ }^{10}$

Berdasarkan pernyataan masyarakat awam di Kota Bengkulu sejak dahulu memang telah menggunakan daun sirih untuk melakukan perawatan genitalia pada ibu setelah melahirkan baik yang mengalami luka maupun tidak ada luka, dengan cara beberapa daun sirih direbus kemudian airnya yang masih hangat digunakan untuk merendam atau cebok. Tidak ada takaran khusus jumlah daun 
sirih maupun banyaknya air dan mereka juga tidak menggunakan iodin. Lama sembuh yang dialami ibu-ibu ratarata tujuh hari.

Penelitian lain, antiseptik iodin juga digunakan sebagai perawatan luka perineum yang menyatakan bahwa iodin mempunyai sifat antiseptik atau (membunuh kuman) baik bakteri gram positif maupun negatif. Akan tetapi, iodin bersifat iritatif dan lebih toksik bila masuk ke pembuluh darah. Dalam penggunaannya, iodin harus diencerkan terlebih dahulu, hal ini karena iodin dalam konsentrasi tinggi dapat menyebabkan iritasi kulit. Selain itu, iodin dalam penggunaan yang berlebihan dapat menghambat proses granulasi luka. Dalam perawatan luka, secara umum biasanya menggunakan iodin $10 \%$. Eusol adalah merupakan bahan desinfektan yang lazim digunakan pada perawatan luka, eusol ini merupakan golongan desinfektan. Efek dari eusol ini adalah membunuh bakteri atau kuman yang ada di sekitar luka. ${ }^{14}$

Infeksi perineum dapat dihindari bahkan penyembuhan dapat dipercepat bila dilakukan perawatan secara cepat dan tepat, perawatan yang tidak tepat dapat merugikan pasien. Nyeri perineum merupakan sumber masalah yang signifikan bagi banyak perempuan setelah melahirkan, tidak hanya pada periode pascalahir langsung tetapi juga dalam jangka panjang. Luka pascaepisiotomi harus dirawat dengan benar sehingga luka cepat sembuh dan tidak terjadi infeksi. Penyebab infeksi perineum adalah Streptococcus haemoliticus, Staphylococcus aureus dan Eschericia coli. Untuk itu diperlukan teknik yang tepat dalam perawatan luka, dan yang terpenting adalah penggunaan bahan yang tepat dalam perawatan luka. Hal ini sangat penting karena apabila tidak tepat dapat mengakibatkan luka sulit sembuh dan memungkinkan terjadinya infeksi. Petugas harus memahami fisiologi penyembuhan luka dan ditantang untuk memberikan pengkajian luka berdasarkan pengetahuan integritas kulit dan pencegahan infeksi. Bahan yang biasa digunakan untuk pencegahan infeksi adalah larutan antiseptik. ${ }^{14}$

Berdasarkan pendapat ahli dan hasil penelitian tersebut bahwa daun sirih merah mengandung zat kimia yang dapat digunakan sebagai antiseptik dan antimikroba yang efektif sehingga dapat digunakan sebagai obat luar atau antiseptik bagi ibu postpartum yang mengalami luka perineum untuk mencegah terjadinya infeksi, mengurangi rasa tidak nyaman dan bahkan mempercepat kesembuhan luka perineum apalagi perineum selalu dalam keadaan tertutup dan selalu basah karena adanya cairan lokhea yang keluar dari rahim, selain itu infusum ini juga menghilangkan bau khas lokhea bercampur iodin yang tidak mengenakkan.

\section{Kesimpulan}

Berdasarkan hasil penelitian tentang efektivitas daun sirih merah dalam perawatan luka perineum dapat disimpulkan bahwa rata-rata lama penyembuhan luka perineum dengan menggunakan infusum daun sirih merah adalah 3 - 4 hari, sedangkan lama penyembuhan dengan menggunakan iodin rata-rata 5 - 6 hari. Berarti perawatan luka perineum pada ibu nifas lebih efektif menggunakan infusum sirih merah daripada iodin, karena ratarata lama hari penyembuhan lebih pendek menggunakan infusum sirih merah dari pada menggunakan iodin, walaupun peneliti lain berpendapat bahwa lama penyembuhan luka ada hubungan yang signifikan dengan kadar hemoglobin. ${ }^{10}$ Infusum daun sirih merah sekaligus menghilangkan bau tidak sedap pada genitalia pada ibu yang mengalami luka perineum postpartum.

\section{Saran}

Beberapa hal yang dapat dijadikan rekomendasi dari hasil penelitian ini yaitu bagi pelayanan kebidanan di Bidan Praktik Mandiri (BPM), bidan merupakan tenaga kesehatan yang paling dekat dengan masyarakat, kemungkinan besar masyarakat percaya dengan bidan, karena itu bidan dalam memberikan pelayanan harus maksimal supaya pasien merasa puas. Sebaiknya bidan setelah menolong persalinan seyogyanya dilanjutkan dengan perawatan terhadap ibu maupun bayinya, terutama pada ibu yang mengalami luka perineum dengan jahitan, diharapkan bidan dapat menyampaikan kepada pasien cara perawatan luka perineum dengan menggunakan daun sirih merah dan cara pembuatan infusum dengan cara yang murah, mudah, dan aman.

\section{Daftar Pustaka}

1. Widyaningrum. Pengaruh pendidikan kesehatan tentang perawatan episiotomi terhadap tingkat pengetahuan pada ibu postpartum di RSUD Sleman. Yogyakarta: UMY; 2011.

2. Cunninghum FG. Obstetri Williams. Edisi ke-21. Jakarta: EGC; 2005.

3. Prawirohardjo S. Ilmu kebidanan. Edisi ke-3. Wiknjosastro H, Saifuddin AB, Rachimadi T, editor. Jakarta: Yayasan Bina Pustaka Sarwono Prawirohardjo; 2007.

4. Saifuddin. Buku panduan praktis pelayanan kesehatan maternal dan neonatal. Jakarta: Yayasan Bina Pustaka Sarwono Prawirohardjo; 2001

5. Doengoe ME, Moorhouse MF, Geissler AC. Nursing care plans: guidelines for planning and documenting patients care. Kariasa IM, penterjemah. Jakarta: EGC; 1999.

6. Smeltzer. Keperawatan medikal bedah. Jakarta: EGC; 2002.

7. Zubier F, Bramono K, Widaty S, Nilasari H, Louisa M, Rosana Y. Efikasi sabun ekstrak sirih merah dalam mengurangi gejala keputihan fisiologis, efikasi sabun ekstrak sirih merah dalam mengurangi gejala keputihan fisiologis. Majalah Kedokteran Indonesia. 2010; 60: 9-14.

8. Juliantina RF, Citra MDA, Nirwani B, Nurmasitoh T, Bowo ET. Manfaat sirih merah sebagai agen antbakterial terhadap bakteri gram positif dan gram negatif. Jurnal Kedokteran dan Kesehatan Indonesia [online]. 2010 [diakses tanggal 21 November 2011]. Diunduh dalam: journal.uii.ac.id/index.php/JKKI/article/download/543/467 2010. 
9. Wibawati PA. Pengaruh ekstrak daun sirih merah (Piperbetle Var. Rubrum) terhadap waktu kesembuhan luka insisi yang diinfeksi Staphylococcus aureus pada tikus putih [tesis]. Surabaya: Universitas Airlangga; 2012.

10. Syahidah. Berbagai khasiat daun sirih untuk kesehatan [online]. 2011 [diakses tanggal 13 Desember 2012]. Diunduh dalam: http://www.voaislam,com/news/voice of Islam sehat-nabawi/2011/07/21/15623/. 2011.

11. DD SLI, Ratnawati R, Berlian I. Hubungan mobilisasi dini dengan kecepatan kesembuhan luka perineum pada ibu postpartum di seluruh wilayah kerja Puskesmas Singosari Kabupaten Malang. Jurnal Keperawatan [online]. 2012 [diakses tanggal 22 Juli 2012]. Diunduh dalam: http://ejournal.umm.ac.id/index.php/keperawatan/article/viewFile/1050/1133_umm_scientific_journal.pdf
12. Bidin Z. Sirih merah sebagai tanaman obat multifungsi [online]. 2012 [diakses tanggal 12 Januari 2013]. Diunduh dalam: http://www.scribd.com/ doc/ 4806075/2012.

13. Anonimous. Sediaan gel ekstrak daun sirih. Majalah Farmasi [online]. 2006; 164 [diakses tanggal 20 Februari 2011]. Diunduh dalam: ml.scribd.com/doc/ 168 805358/gel-sirih,2006

14. Bago E. Manfaat dan khasiat daun sirih [online]. 2011 [diakses tanggal 15 Juli 2012]. Diunduh dalam: coconian.com. Coconias Blog Host in Blogger.

15. Haniah M. Isolasi jamur endofit dari daun airih (Piper Betle L) aebagai antimikroba terhadap Escherichia coli, Staphylococus aureus dan Candida albicans [tesis] [diakses tanggal 17 Februari 2011]. 2008. p. 56-70. Diunduh dalam: http://lib.uin-malang.ac.id/files/thesis/fullahrpter/0352005. 